Article

\title{
Subtractive Inhibition Assay for the Detection of E. coli O157:H7 Using Surface Plasmon Resonance
}

\section{Yixian Wang, Zunzhong Ye*, Chengyan Si and Yibin Ying}

College of Biosystems Engineering and Food Science, Zhejiang University, Hangzhou 310029, Zhejiang, China; E-Mails:wang_yi_xian1986@sina.com (Y.W.); sichengyanzhj@163.com (C.S.); ybying@zju.edu.cn (Y.Y.)

* Author to whom correspondence should be addressed; E-Mail: zzye@zju.edu.cn;

Tel.: +86-571-8697-1885; Fax: +86-571-8697-1885.

Received: 8 January 2011; in revised form: 29 January 2011 / Accepted: 21 February 2011/

Published: 1 March 2011

\begin{abstract}
A surface plasmon resonance (SPR) immunosensor was developed for the detection of $E$. coli $\mathrm{O} 157: \mathrm{H} 7$ by means of a new subtractive inhibition assay. In the subtractive inhibition assay, E. coli O157:H7 cells and goat polyclonal antibodies for E. coli $\mathrm{O} 157: \mathrm{H} 7$ were incubated for a short of time, and then the E. coli O157:H7 cells which bound antibodies were removed by a stepwise centrifugation process. The remaining free unbound antibodies were detected through interaction with rabbit anti-goat IgG polyclonal antibodies immobilized on the sensor chip using a BIAcore 3000 biosensor. The results showed that the signal was inversely correlated with the concentration of E. coli $\mathrm{O} 157: \mathrm{H} 7$ cells in a range from $3.0 \times 10^{4}$ to $3.0 \times 10^{8} \mathrm{cfu} / \mathrm{mL}$ with a detection limit of $3.0 \times 10^{4} \mathrm{cfu} / \mathrm{mL}$. Compared with direct SPR by immobilizing antibodies on the chip surface to capture the bacterial cells and ELISA for E. coli O157:H7 (detection limit: both $3.0 \times 10^{5} \mathrm{cfu} / \mathrm{mL}$ in this paper), the detection limit of subtractive inhibition assay method was reduced by one order of magnitude. The method simplifies bacterial cell detection to protein-protein interaction, which has the potential for providing a practical alternative for the monitoring of E. coli O157:H7 and other pathogens.
\end{abstract}

Keywords: subtractive inhibition assay; SPR; E. coli O157:H7 


\section{Introduction}

In recent times, E. coli $\mathrm{O} 157: \mathrm{H} 7$ as one of the major foodborne pathogenic bacteria and as such has attracted considerable attention. According to the U.S. Center for Disease Control and Prevention (CDC), outbreak data and the known ability of the organism to be passed from person to person in nursing homes, day-care centers, and other personal care facilities, indicate that the presence of as few as 10 E. coli $\mathrm{O} 157: \mathrm{H} 7$ could result in disease. It has been reported that there may be about 73,000 infections and 61 deaths occurring due to E. coli O157:H7 each year in the United States [1] and therefore it is of utmost importance to develop rapid and sensitive methods for E. coli O157:H7 detection.

By far, the most popular detection methods are culture and colony counting methods, polymerase chain reaction (PCR) and immunology-based methods and biosensors [2-6]. However, they are labor intensive and time consuming or professional operation limited. Biosensors, which incorporate a bioreceptor closely integrated with or connected to a transducer $[7,8]$, have been proved to be a promising method for bacteria detection due to their portability, speed, sensitivity and possibility of on-the-spot detection [6,7,9], Surface plasmon resonance (SPR) biosensors are one kind of biosensor that has been widely used for bacterial detection [10-14]. A large number of direct SPR immunosensors have been used for the detection of bacterial cells by immobilizing antibodies directly on the chip surface to capture the bacterial cells [15-20]. Mazumdar immobilized antibodies on gold surface of each glass prism to capture $S$. typhimurium using the Plasmonic ${ }^{\circledR}$ SPR assay with a detection limit of $1.25 \times 10^{5} \mathrm{cfu} / \mathrm{mL}$ [20]. Subramanian reported that the detection limit of direct surface plasmon resonance assay for Escherichia coli O157:H7 detection was $10^{6} \mathrm{cfu} / \mathrm{mL}$ [17]. The method based on the surface capture of cells has some limits to reduce the sensitivity of immunosensors [21-24]. Firstly, the effective penetration depth of the evanescent field which arises under conditions of total internal reflection is approximately $300 \mathrm{~nm}$. It means that only refractive index changes occurring within the $300 \mathrm{~nm}$ distance from the surface will cause a change in the generated SPR signal. Bacteria such as E. coli O157:H7 with size of about $1 \mu \mathrm{m}$ probably only interact with the top of the dextran layer that coats the gold surface and therefore only a small portion of the cell which is in close contact with the sensor surface will produce a measurable signal, which decreases the sensitivity of SPR for E. coli O157:H7 detection [21-24]. In addition, due to the large size of bacterial cells, direct cell binding requires that the cell-antibody binding affinity must be high to withstand the effect of shear force created by the laminar flow in the microflow channels [24]. Finally, Biacore instruments average the SPR angle over an area of approximately $0.25 \mathrm{~mm}^{2}$ on the sensor surface. As the sizes of bacterial cells are large, they will not evenly cover the area measured due to steric hindrance, which will decrease the signal response [24].

In this paper, to avoid the defects of SPR detection due to the size of bacteria, a new subtractive inhibition assay using SPR detection of E. coli O157:H7 was developed. In the proposed assay, E. coli O157:H7 cells and antibodies were incubated for a short of time, and the E. coli O157:H7 cells which bound antibodies were removed by a stepwise centrifugation process. Then the remaining free unbound antibodies were quantified through binding with anti-antibody immobilized on the sensor chip using BIAcore 3000 biosensor, which were inversely proportional to the E. coli O157:H7 cell 
concentration (Figure 1). This method simplifies bacterial cells detection to protein-protein interaction, which increases sensitivity of SPR for E. coli O157:H7 detection.

Figure 1. Principle of a subtractive inhibition assay (SIA) using SPR.

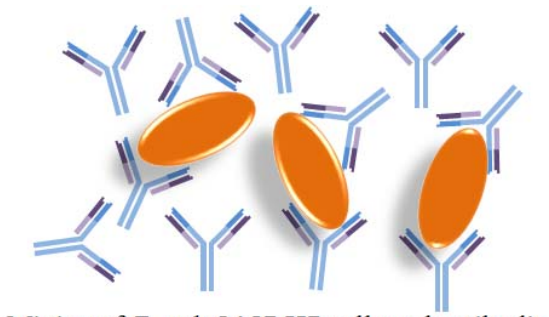

Mixing of E. coli $\mathrm{O} 157: \mathrm{H} 7$ cells and antibodies

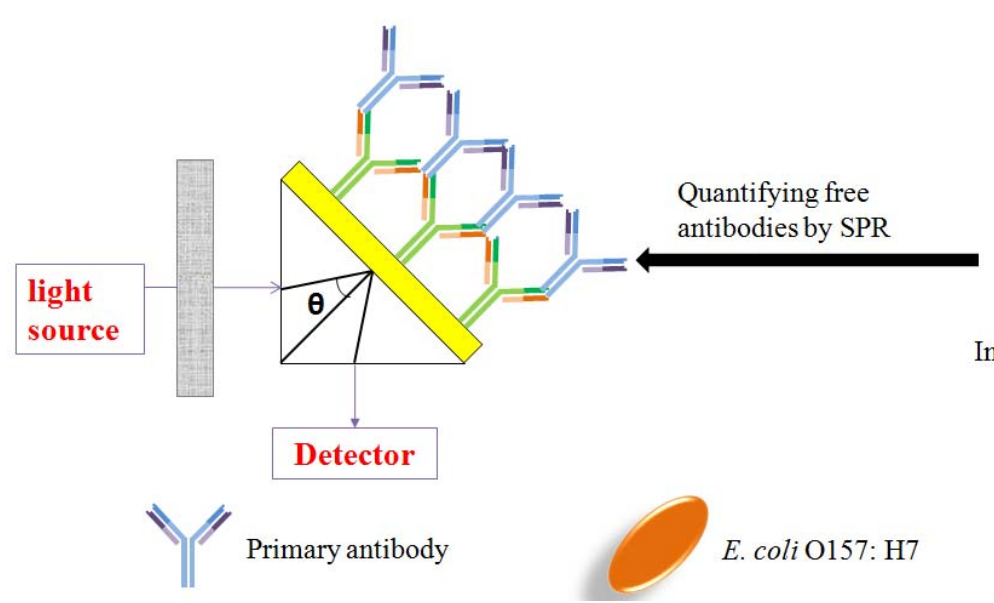

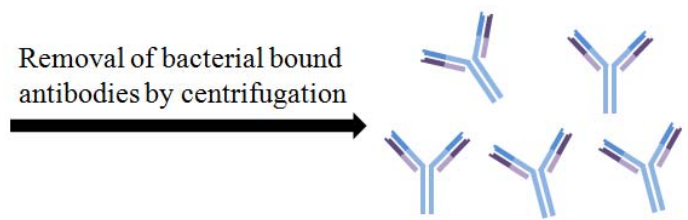

Remaining free bound antibodies

Inject free antibodies to bind with secondary antibodies
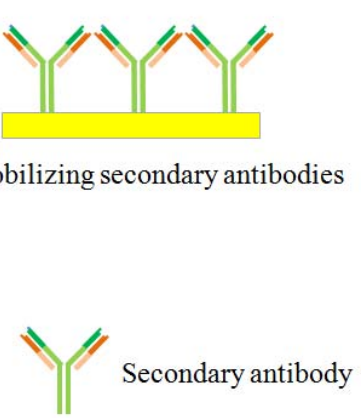

\section{Experimental Section}

\subsection{Regents}

The reagents were obtained from the following sources: goat polyclonal antibody for E. coli $\mathrm{O} 157: \mathrm{H} 7$ and E. coli O157:H7 positive control were from KPL (Gaithersburg, MD, USA); E. coli DH5a (ATCC PTA-3137) was obtained from College of Food Science at Zhejiang University; Rabbit anti-goat IgG polyclonal antibody was from Boster (Wuhan, China); Sensor chip CM5, HBS running buffer (10 mM HEPES, $150 \mathrm{mM} \mathrm{NaCl}, 3.8 \mathrm{mM}$ EDTA, 0.05\% (v/v) Tween), $10 \mathrm{mM}$ acetate buffer $(\mathrm{pH} 4.5)$ and $1 \mathrm{M}$ ethanolamine $(\mathrm{pH}$ 8.5) were from GE Healthcare Bio-Sciences AB (Uppsala, Sweden); Phosphate buffered saline (PBS, pH 7.4), N-hydroxysuccinimide (NHS) and $N$-ethyl- $N$-(dimethylaminopropyl) carbodiimide hydrochloride (EDC) were from Sigma (St. Louis, MO, USA). All other regents were all chemical analytical grades.

\subsection{ELISA for E. coli O157:H7 Detection}

Microtiter plates were coated with $100 \mu \mathrm{L}$ of $10 \mu \mathrm{g} / \mathrm{mL}$ of goat polyclonal antibodies for E. coli $\mathrm{O} 157: \mathrm{H} 7$ in phosphate buffered saline (PBS) overnight at $4{ }^{\circ} \mathrm{C}$, and then washed three times with PBS $+0.05 \%$ Tween-20 (PBST). $300 \mu \mathrm{L} 3 \%$ bovine serum albumin (BSA) was used to block unbound sites each plate for $30 \mathrm{~min}$, followed washing with PBST for three times. One hundred $\mu \mathrm{L}$ of E. coli O157:H7 samples of different concentration from $3.0 \times 10^{2}-3.0 \times 10^{8} \mathrm{cfu} / \mathrm{mL}$ were loaded onto each plate and incubated for $1 \mathrm{~h}$ at room temperature. The plates were washed three times with PBST 
and then $100 \mu \mathrm{L}$ 1,000-fold decreasing dilutions of peroxidase-conjugated affinipure donkey anti-goat $\operatorname{IgG}(\mathrm{H}+\mathrm{L})$ was added to each well. Following $30 \mathrm{~min}$ incubation and a final wash step, the plates were developed with TMB, stopped after 10 min with $\mathrm{H}_{2} \mathrm{SO}_{4}$ and read at a wavelength of $450 \mathrm{~nm}$ on a spectrophotometer.

\subsection{Direct SPR by Immobilizing Antibodies on the Chip Surface to Capture the Bacterial Cells}

After activation by injecting $70 \mu \mathrm{L}$ mixture of 0.1 M NHS with $0.4 \mathrm{M} \mathrm{EDC}$ at $10 \mu \mathrm{L} / \mathrm{min}$ for $7 \mathrm{~min}$, a $100 \mu \mathrm{g} / \mathrm{mL}$ goat polyclonal antibody for E. coli $\mathrm{O} 157: \mathrm{H} 7$ in $10 \mathrm{mM}$ acetate buffer, $\mathrm{pH} 4.5$, was injected over the chip surface at $10 \mu \mathrm{L} / \mathrm{min}$ for $10 \mathrm{~min}$. Unreacted sites were subsequently deactivated by injecting $1 \mathrm{M}$ ethanolamine, $\mathrm{pH} 8.5$, at $10 \mu \mathrm{L} / \mathrm{min}$ for $7 \mathrm{~min}$. Then, different concentration of diluted E. coli O157:H7 $\left(3.0 \times 10^{1}-3.0 \times 10^{8} \mathrm{cfu} / \mathrm{mL}\right)$ in running buffer were flowed for $5 \mathrm{~min}$ at $10 \mu \mathrm{L} / \mathrm{min}$ for direct detection. After the bacterial cells binding, the chip surface was regenerated by injecting $10 \mu \mathrm{L}$ of $15 \mathrm{mM} \mathrm{NaOH}$ every time.

\subsection{Subtractive Inhibition Assay}

\subsubsection{Free Antibody Centrifugation Separation}

Three hundred $\mu \mathrm{L}$ of a $50 \mu \mathrm{g} / \mathrm{mL}$ anti-E. coli O157:H7 polyclonal antibody solution diluted in PBS, pH 7.4, was mixed with $300 \mu \mathrm{L}$ of $E$. coli $\mathrm{O} 157: \mathrm{H} 7$ with series of concentration from $10^{1}-10^{8} \mathrm{cfu} / \mathrm{mL}$. The final anti-E. coli O157:H7 polyclonal antibody concentration was $25 \mu \mathrm{g} / \mathrm{mL}$. Each mixture was incubated in rotating for $1 \mathrm{~h}$ at room temperature, followed stepwise centrifugation process for $2 \mathrm{~min}$ intervals at $50,200,400,800,1,200,1,800$ and $3,200 \times \mathrm{g}$ to separate the cells bound antibodies from the remaining free unbound antibodies. Get the remaining free unbound antibodies by drawing $500 \mu \mathrm{L}$ supernatant fluids from the centrifugal tube.

\subsubsection{Antibody Immobilization and Assay Setup}

The remaining free unbound antibodies were quantified using a BIAcore 3000TM instrument. The CM 5 sensor chip was activated by injecting $70 \mu \mathrm{L}$ mixture of $0.1 \mathrm{M}$ NHS with $0.4 \mathrm{M}$ EDC at $10 \mu \mathrm{L} / \mathrm{min}$ for $7 \mathrm{~min}$. A $100 \mu \mathrm{g} / \mathrm{mL}$ rabbit anti-goat (Fab portion) polyclonal antibodies in $10 \mathrm{mM}$ acetate buffer, $\mathrm{pH} 4.5$, were injected over the chip surface at $10 \mu \mathrm{L} / \mathrm{min}$ for $10 \mathrm{~min}$. Unreacted sites were subsequently deactivated by injecting $1 \mathrm{M}$ ethanolamine, $\mathrm{pH} 8.5$, at $10 \mu \mathrm{L} / \mathrm{min}$ for $7 \mathrm{~min}$. Then the remaining free unbound antibodies were injected in the chip surface to bind with the secondary antibodies. After the antibodies binding, the chip surface was regenerated by injecting $10 \mu \mathrm{L}$ of $15 \mathrm{mM}$ $\mathrm{NaOH}$ every time.

\subsection{Specificity Testing}

The specificity of the biosensor was confirmed by detecting E. coli DH5a, one of E. coli serotypes. $300 \mu \mathrm{L} 3.0 \times 10^{8} \mathrm{cfu} / \mathrm{mL}$ E. coli DH5 $\alpha$ mixed with $300 \mu \mathrm{L}$ of a $50 \mu \mathrm{g} / \mathrm{mL}$ anti-E. coli O157:H7 polyclonal antibody solution. And then the mixture was with the same free antibody centrifugation separation and detection method as E. coli O157:H7 detection. 


\section{Results and Discussion}

\subsection{ELISA for Validity of Antibody for E. coli O157:H7 Detection}

ELISA analysis was used as a conventional immunoassay method for comparison with the biosensor method, and to observe the quality of the E. coli O157:H7 antibodies used in the immunosensor. Eight concentrations of E. coli O157:H7 $\left(3.0 \times 10^{1}\right.$ to $\left.3.0 \times 10^{8} \mathrm{cfu} / \mathrm{mL}\right)$ were assayed with the ELISA, and the results are shown in Figure 2. From $3.0 \times 10^{5} \mathrm{cfu} / \mathrm{mL}$, increasing the bacteria concentration resulted in an increase of OD value $(2.9647,2.5363,1.4685$ and 0.6323 observed with $3.0 \times 10^{8}, 3.0 \times 10^{7}, 3.0 \times 10^{6}, 3.0 \times 10^{5} \mathrm{cfu} / \mathrm{mL}$ E. coli O157:H7 cells respectively). And the standard deviation (SD) for each point of the standard curves $\left(3.0 \times 10^{8}, 3.0 \times 10^{7}, 3.0 \times 10^{6}, 3.0 \times 10^{5} \mathrm{cfu} / \mathrm{mL}\right.$ and control) were $1.5 \%, 2.0 \%, 1.2 \%, 0.9 \%, 2.2 \%$, respectively. The results indicated that the purchased anti-E. coli O157:H7 antibody allowed the detection of E. coli O157:H7. The detection limit of this ELISA was $3.0 \times 10^{5} \mathrm{cfu} / \mathrm{mL}$ of E. coli O157:H7.

Figure 2. Detection of E. coli O157:H7 based on ELISA.

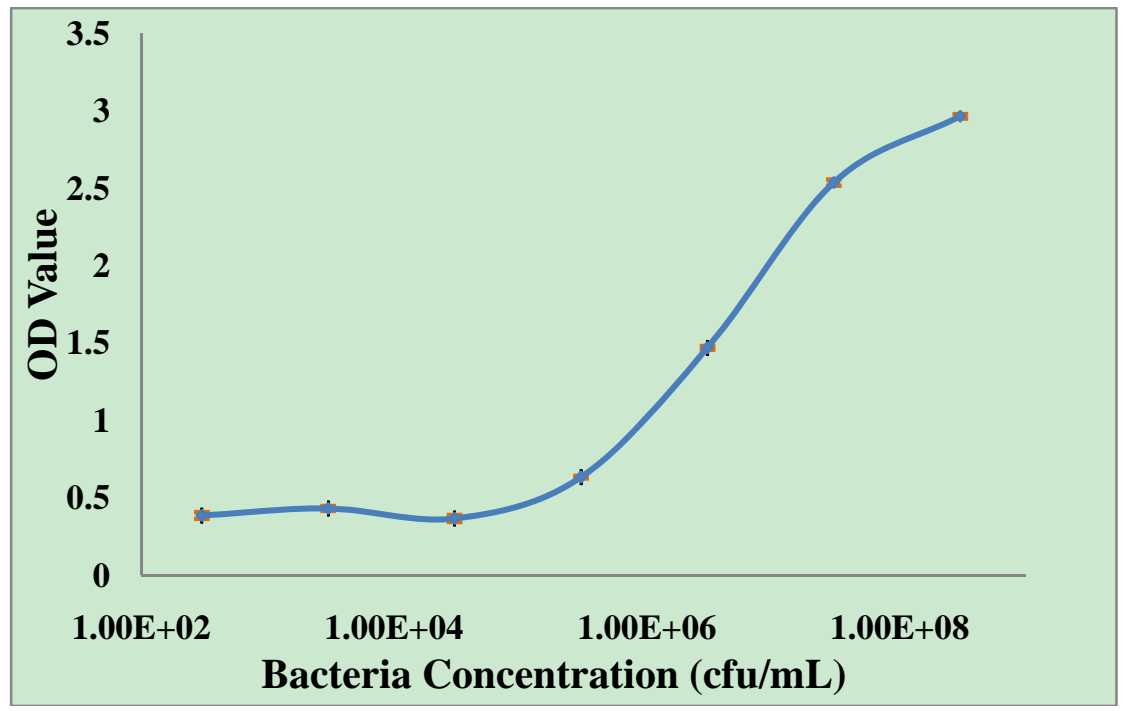

\subsection{Direct SPR Immobilizing Antibodies on the Chip Surface to Capture the Bacterial Cells}

The first step of the direct assay was the immobilization of the capture antibodies on the CM5 chip surface, and a significant increase in the sensorgram signal $(R U=17,000)$ was observed, indicating a stable binding interaction between the CM5 chip surface and the captured antibody. The incubation time was only $10 \mathrm{~min}$. Through immobilizing antibodies directly on the chip surface to capture the bacterial cells, a detectable change in RU due to its binding to the bacterial cells was obtained only at and above a cell concentration of $3.0 \times 10^{5} \mathrm{cfu} / \mathrm{mL}$. 47, 76, 160 and 288 RU observed from binding with $3.0 \times 10^{5}, 3.0 \times 10^{6}, 3.0 \times 10^{7}, 3.0 \times 10^{8} \mathrm{cfu} / \mathrm{mL}$ E. coli O157:H7 cells, respectively. The standard deviation (SD) for each point of the standard curves $\left(3.0 \times 10^{8}, 3.0 \times 10^{7}, 3.0 \times 10^{6}, 3.0 \times 10^{5} \mathrm{cfu} / \mathrm{mL}\right.$ and control) were $8.1 \%, 2.4 \%, 4.7 \%, 3.3 \%, 3.1 \%$, respectively. The lower limit of detection (LLD) is defined as the concentration of cells resulting in a detection signal that is the average value of the detection signal obtained due to control plus 3 times the standard deviation [20]. The detection range was between $3.0 \times 10^{5}$ and $3.0 \times 10^{8} \mathrm{cfu} / \mathrm{mL}$ with a limit of detection of $3.0 \times 10^{5} \mathrm{cfu} / \mathrm{mL}$. 


\subsection{Centrifugation Effect}

Haines et al. have reported removal of the cells-bound antibodies by a method such as filtration, however, that method was not suitable for complex and viscous matrices [25]. It has been reported that separate the remaining free antibodies from the bacterial cells-bound antibodies by centrifugation for 1 min intervals at 50, 200, 450, 800,1,200,1,800 and 3,200 $\times \mathrm{g}$ was possible [23]. Therefore, in this paper, a stepwise centrifugation process has been applied to separate the remaining free unbound antibodies from the bacterial cells that bound antibodies. But according to the above method, the signal of $10^{8} \mathrm{cfu} / \mathrm{mL}$ was larger than the signal of $3.0 \times 10^{7} \mathrm{cfu} / \mathrm{mL}$, possibly because the sizes of E. coli O157:H7 cells (about $1 \mu \mathrm{m}$ ) are smaller than Listeria monocytogenes cells, resulting in the need for greater centrifugal force and longer centrifugation times, so we increased the centrifugation time by centrifuging for $2 \mathrm{~min}$ intervals at 50,200, 400, 800, 1,200, 1,800 and 3,200 $\times$ g, confirming the method's principle, resulting in a decreasing signal with increasing E. coli O157:H7 bacteria cell concentration. Optimization of the centrifugation time according to the size of E. coli O157:H7 cells was the key step for the success of this experiment.

\subsection{Sensor Chip Preparation}

The subtractive inhibition assay was further implemented into a Biacore ${ }^{\circledR} 3000$ SPR sensor. The scheme for the sensor setup used in this work is shown in Figure 1. The dextran layer was immobilized on the gold surface of CM5 chip beforehand. Then the surface was activated with an NHS-EDC solution, washed with running buffer, and a goat anti-mouse IgG polyclonal antibody was immobilized to a CM5 chip surface $(17,556 \mathrm{RU})$ through an amide bond, as shown in Figure 3. The binding response was compared to that of a reference channel chip surface (same activation using EDC and NHS, blocking using ethanolamine, but without immobilizing secondary antibody), which gave insignificant binding, thereby illustrating the specificity of the binding response (data not shown).

Figure 3. Plot of sensor chip preparation: (A) activation. (B) rabbit anti-goat IgG polyclonal antibodies immobilization. (C) ethanolamine blocking.

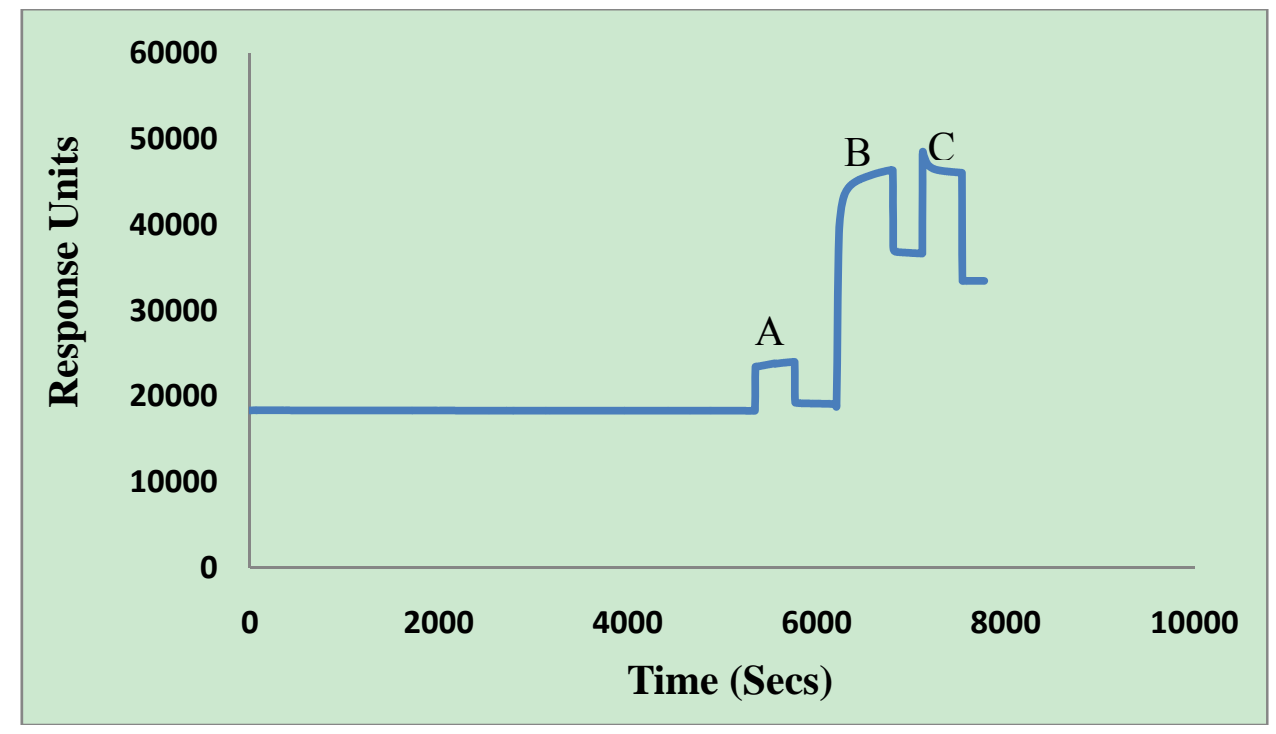




\subsection{Surface Regeneration}

The rabbit anti-goat IgG polyclonal antibodies were immobilized on the CM5 chip and optimal regeneration conditions were investigated. The regeneration solution should remove the remaining free antibodies from the anti-goat IgG polyclonal antibodies without affecting the activity of the secondary antibodies. The regeneration solution of $10 \mu \mathrm{L} 15 \mathrm{mM} \mathrm{NaOH}$ at a flow rate of $10 \mu \mathrm{L} / \mathrm{min}$ was sufficient for surface regeneration. The surface activity of the chip decreased $6.0 \%$ by repeated 50 binding and regeneration cycles, which proved the excellent long-term surface performance.

\subsection{Sensor Performance}

In the subtractive inhibition assay, different concentrations of $E$. coli $\mathrm{O} 157: \mathrm{H} 7$ cells and antibodies were incubated and then the E. coli O157:H7 cells which bound antibody were removed by a stepwise centrifugation process. The samples of free unbound antibodies were quantified in duplicate out of order through binding with anti-antibody immobilized on the sensor chip using BIAcore 3000 biosensor. As expected, and as shown in Figure 4, the binding responses were inversely proportional to the concentration of the E. coli O157:H7 cells, which verified the subtractive inhibition assay principle. 166, 285, 373, 389, 419 and 449 RU observed from supernatants from samples incubated with $3.0 \times 10^{8}, 3.0 \times 10^{7}, 3.0 \times 10^{6}, 3.0 \times 10^{5}, 3.0 \times 10^{4}$ and $0 \mathrm{cfu} / \mathrm{mL}$ E. coli O157:H7 cells, respectively.

Figure 4. Overlay plot from one assay demonstrating that the binding response is inversely proportional to the E. coli O157:H7 concentration: (A) control sample. (B) $3.0 \times 10^{4} \mathrm{cfu} / \mathrm{mL}$. (C) $3.0 \times 10^{5} \mathrm{cfu} / \mathrm{mL}$. (D) $3.0 \times 10^{6} \mathrm{cfu} / \mathrm{mL}$. (E) $3.0 \times 10^{7} \mathrm{cfu} / \mathrm{mL}$. (F) $3.0 \times 10^{8} \mathrm{cfu} / \mathrm{mL}$.

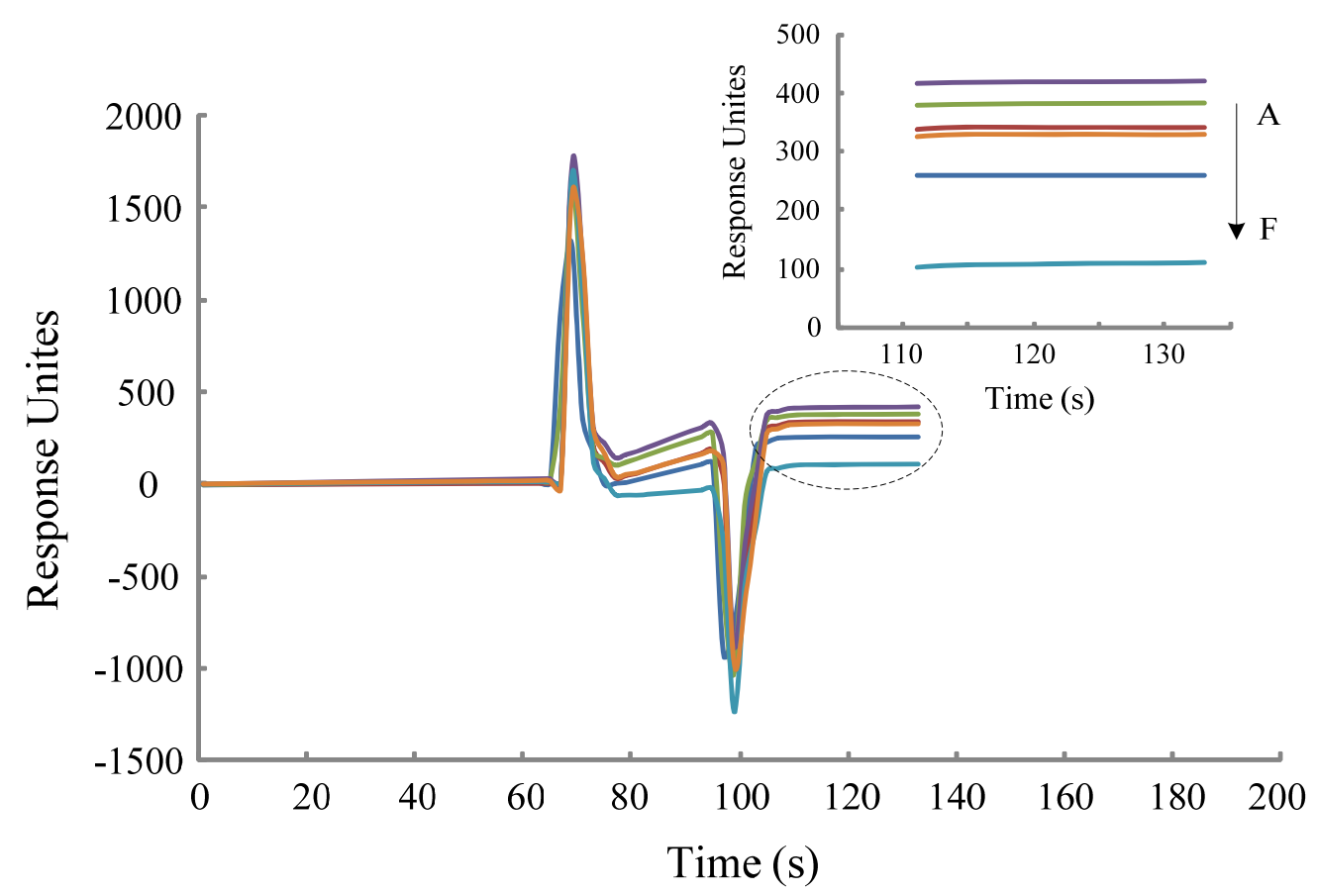

The resonance dips of different bacterial cells concentration from $3.0 \times 10^{8}$ to $3.0 \times 10^{4}$ were 283 , 164, 76, 60 and 30, respectively. The signal was correlated with the concentration of E. coli O157:H7 cells in a range from $3.0 \times 10^{8}$ to $3.0 \times 10^{4} \mathrm{cfu} / \mathrm{mL}$. Normalized data $\left(\mathrm{R} / \mathrm{R}_{0}\right)$ was obtained with the 
average response for each sample $(\mathrm{R})$ divided by the average of the control (sample without bacterial cells, $\left.\mathrm{R}_{0}\right)$. A calibration curve using normalized data $\left(\mathrm{R} / \mathrm{R}_{0}\right)$ plotted against the E. coli $\mathrm{O} 157: \mathrm{H} 7$ cells concentrations, was constructed (Figure 5). According to Figure 5, the range of detection was found to be approximately $3.0 \times 10^{4}-3.0 \times 10^{8} \mathrm{cfu} / \mathrm{mL}$. The standard deviations for each point of the standard curves $\left(3.0 \times 10^{8}, 3.0 \times 10^{7}, 3.0 \times 10^{6}, 3.0 \times 10^{5}, 3.0 \times 10^{4} \mathrm{cfu} / \mathrm{mL}\right)$ were $7.6 \%, 1.7 \%, 3.1 \%, 5.1 \%$, $1.7 \%$, respectively, which illustrates the good reproducibility of the immunoassay.

Figure 5. The plot between SPR response and bacterial cells concentration.

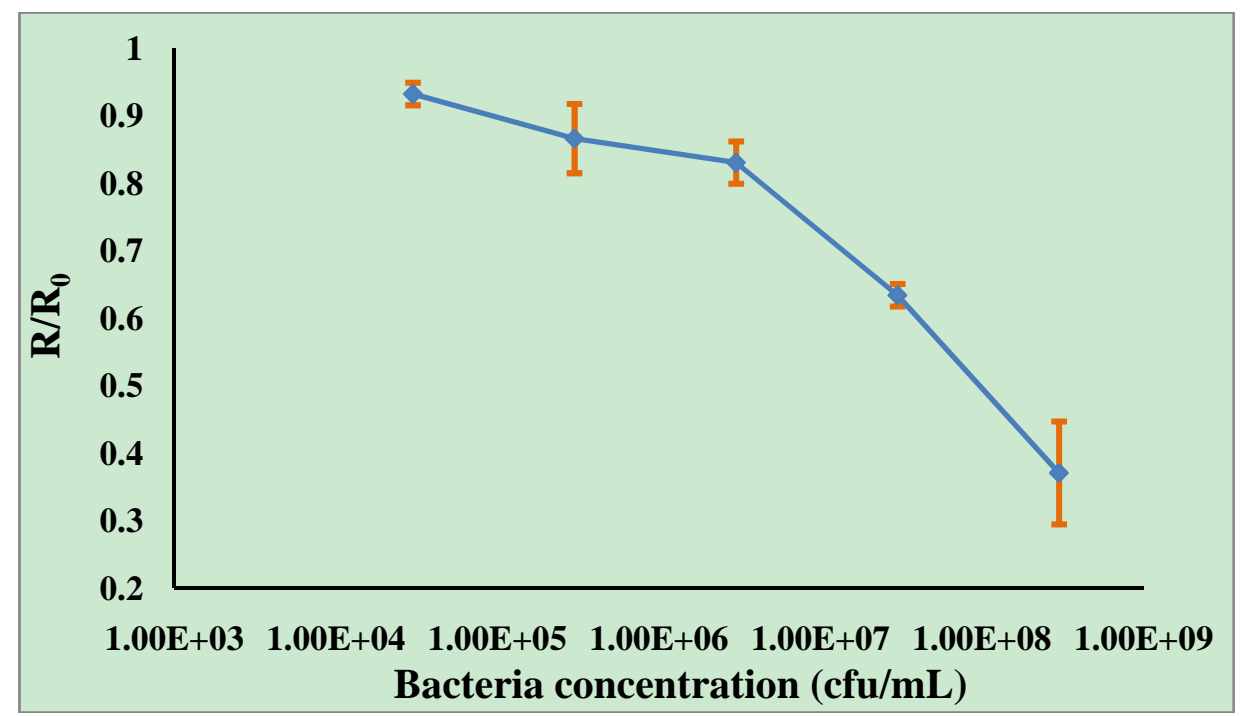

In the subtractive inhibition assay, the lower limit of detection (LLD) is defined as the concentration of cells resulting in a detection signal that is the average value of the detection signal obtained due to control minus three times the standard deviation. The relative standard deviation for control samples was $3.5 \%$. Therefore, the detection limit of SPR detection based on subtractive inhibition assay is $3.0 \times 10^{4} \mathrm{cfu} / \mathrm{mL}$, which is one order of magnitude less compared with direct SPR detection immobilizing antibodies on the chip surface to capture the bacterial cells and ELISA method for E. coli O157:H7 detection (the detection limit: both $3.0 \times 10^{5} \mathrm{cfu} / \mathrm{mL}$ ). That method is of significance because there have been problems encountered in the use of SPR for bacterial cell detection. It simplifies bacterial cells detection to protein-protein interaction, which avoid the defects of SPR detection due to the size of bacteria, including the cell size exceeding the $300 \mathrm{~nm}$ range of the evanescent field wave, high fluid force acting on captured cells, and limited mass transfer. Therefore the subtractive inhibition assay has improved the sensitivity of the sensors for E. coli O157:H7 detection.

The traditional culture and colony counting method has been a practical method for the detection and identification of E. coli $\mathrm{O} 157: \mathrm{H} 7$ in food, including microbiological culturing and isolation of the pathogen, followed by confirmation by biochemical and serological tests, which takes up to 5-7 days to get a confirmed result [26]. Although it can provide reliable results, it is time consuming, which is not suitable for rapid assay for E. coli O157:H7 and other pathogens in the food industry. The polymerase chain reaction (PCR) and enzyme-linked immunosorbent assay (ELISA) are a lot less time-consuming than the traditional culture and colony counting methods, and usually take 4-5 hours to produce detection result [6,27]. Compared with above mentioned methods for E. coli O157:H7 
detection, the subtractive inhibition assay based on SPR, excluding sample incubation, centrifugation, secondary antibodies immobilization and interaction time, was less than $2 \mathrm{~h}$. It has reduced the testing time effectively and can detect multiple samples in succession with the process of regeneration, which have the potential for providing a practical alternative for the monitoring of E. coli O157:H7 and other pathogens in the food industry.

\subsection{Specificity of the Biosensor}

The specificity of the biosensor was confirmed by detecting E. coli DH5a, one of E. coli serotypes. For E. coli DH5 $\alpha$ (the concentration of $3.0 \times 10^{8} \mathrm{cfu} / \mathrm{mL}$ ), the response signal was 412 , while the response signal of E. coli O157:H7 cells $\left(3.0 \times 10^{8} \mathrm{cfu} / \mathrm{mL}\right)$ was 166 . The E. coli O157:H7 gave a binding response of 283 and weak reactivity was found with E. coli DH5 $\alpha$ with a signal dip of 37 (Figure 6). This suggests that E. coli DH5 $\alpha$ did not have strong binding force with anti-E. coli O157:H7 polyclonal antibodies as E. coli $\mathrm{O} 157: \mathrm{H} 7$, demonstrating specificity of the biosensor in the presence of non-target bacterial cells.

Figure 6. The cross-reactivity studies plot between E. coli O157:H7 and E. coli DH5 $\alpha\left(3.0 \times 10^{8}\right)$.

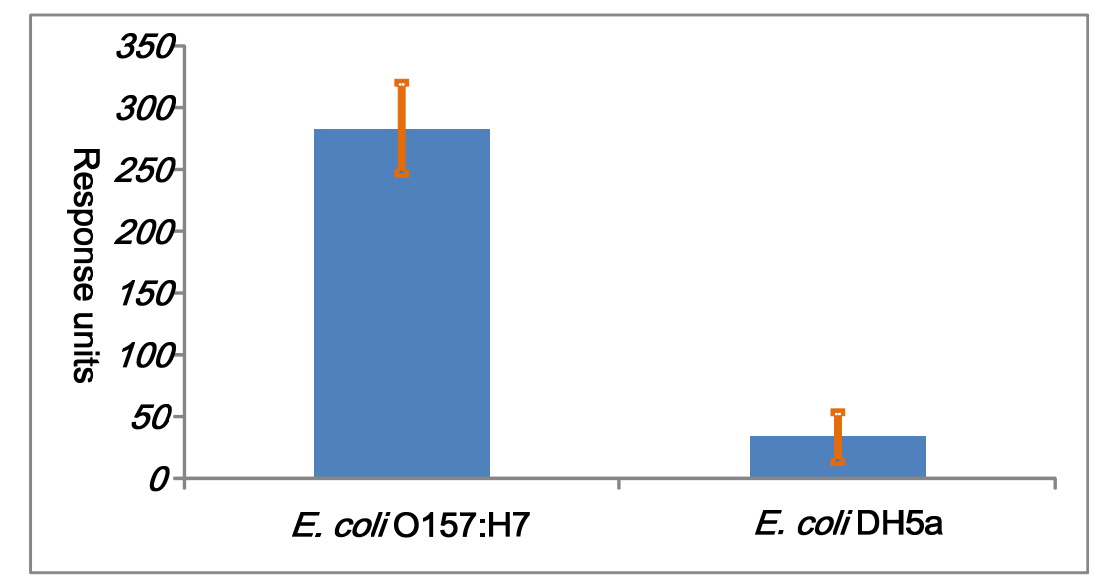

\section{Conclusions}

A new subtractive inhibition assay using SPR detection of E. coli O157:H7 has been clearly established. Unlike the direct SPR for bacterial detection by immobilizing the antibody on the chip surface, in the subtractive inhibition assay, the remaining free unbound antibodies obtained by stepwise centrifugation process after E. coli O157:H7 cells and relevant antibodies incubation, were detected through interaction with secondary antibody immobilized on the sensor chip using a BIAcore 3000 biosensor. The results showed that the signal was inversely correlated with the concentration of E. coli $\mathrm{O} 157: \mathrm{H} 7$ cells in a range from $3.0 \times 10^{4}$ to $3.0 \times 10^{8} \mathrm{cfu} / \mathrm{mL}$. The detection limit was $3.0 \times 10^{4} \mathrm{cfu} / \mathrm{mL}$, compared with direct SPR by immobilizing antibodies on the chip surface to capture the bacterial cells and ELISA methods with the same bacterial cells and relevant antibodies (detection limit: $3.0 \times 10^{5} \mathrm{cfu} / \mathrm{mL}$ in this paper), the detection limit of subtractive inhibition assay method was reduced by one order of magnitude. The subtractive inhibition assay method simplified bacterial cell detection to protein-protein interaction, and can increase the sensitivity of SPR biosensors for E. coli O157:H7 detection. The assay time required for sample detection was less than $2 \mathrm{~h}$ and the sample 
requirement for each analysis was only $5 \mu \mathrm{L}$, which reduced the testing time and sample volume effectively compared with the traditional methods for bacterial detection. The present assay can be used in automated mode with the ability to rapidly analyze a large number of samples and has specificity in the presence of non-target bacterial cells.

The subtractive inhibition assay method based on SPR can also be applied to the detection of other organisms suffering from oversize effects, such as virus, bacteria, fungal, cells and so on. The simplicity of this SPR-based subtractive inhibition assay for detection of E. coli O157:H7 clearly demonstrates the potential of the SPR technique to be used as a rapid detection tool for food microbiological safety.

\section{Acknowledgements}

The authors would like to thank the National Natural Science Foundation of China No. 20907041, Zhejiang Provincial QianJiang talent project No. 2008R10027 and Zhejiang Provincial Natural Science Foundation of China No. Y2080914 for funding this project. The authors would like to thank Yanbin Li and Ronghui Wang for their contributions to this research.

\section{References and Notes}

1. Mead, P.S.; Slutsker, L.; Dietz, V.; McCaig, L.F.; Bresee, J.S.; Shapiro,C.; Griffin, P.M.; Tauxe, R.V. Food-related illness and death in the United States. Emerg. Infect. Dis. 1999, 5, 607-625.

2. Hall, R.H. Biosensor technologies for detecting microbiological foodborne hazards. Micro. Infect. 2002, 4, 425-432.

3. Swaminathan, B.; Feng, P. Rapid detection of foodborne pathogenic bacterial. Annu. Rev. Microbiol. 1994, 48, 401-426.

4. de Boer, E.; Beumer, R.R. Methodology for detection and typing of foodborne microorganisms. Int. J. Food Microbiol. 1999, 50, 119-130.

5. Gracias, K.S.; McKillip, J.L. A review of conventional detection and enumeration methods for pathogenic bacteria in food. Can. J. Microbiol. 2004, 50, 883-890.

6. Lazcka, O.; Del Campo, F.J.; Munoz, F.X. Pathogen detection: A perspective of traditional methods and biosensors. Biosens. Bioelectron. 2007, 22, 1205-1217.

7. Ivnitski, D.; Abdel-Hamid, I.; Atanasov, P.; Wilkins, E. Biosensors for detection of pathogenic bacteria. Biosens. Bioelectron. 1999, 14, 599-624.

8. Scheller, F.W.; Hintsche, R.; Pfeiffer, D.; Schubert, F.; Riedel, K.; Kindervater, R. Biosensors-Fundamentals applications and trends. Sens. Actuat. B Chem. 1991, 4, 197-206.

9. Ivnitski, D.; Abdel-Hamid, I.; Atanasov, P.; Wilkins, E.; Stricker, S. Application of electrochemical biosensors for detection of food pathogenic bacteria. Electroanalysis 2000, 12, 317-325.

10. Dudak, F.C.; Boyaci, I.H. Rapid and label-free bacteria detection by surface plasmon resonance (SPR) biosensors. Biotech. J. 2009, 4, 1003-1011.

11. Nanduri, V.; Bhunia, A.K.; Tu, S.I.; Paoli, G.C.; Brewster, J.D. SPR biosensor for the detection of L-monocytogenes using phage-displayed antibody. Biosens. Bioelectron. 2007, 23, 248-252. 
12. Piliarik, M.; Parova, L.; Homola, J. High-throughput SPR sensor for food safety. Biosens. Bioelectron. 2009, 24, 1399-1404.

13. Taylor, A.D.; Ladd, J.; Yu, Q.; Chen, S.; Homolaa, J.; Jiang, S. Quantitative and simultaneous detection of four foodborne bacterial pathogens with a multi-channel SPR sensor. Biosens. Bioelectron. 2006, 22, 752-758.

14. Zordan, M.D.; Grafton, M.M.G.; Acharya, G.; Reece, L.M.; Cooper, C.L.; Aronson, A.I.; Park, K.; Leary, J. Detection of Pathogenic E. coli O157:H7 by a Hybrid Microfluidic SPR and Molecular Imaging Cytometry Device. Cytometry A 2009, 75A, 155-162.

15. Eum, N.S.; Yeom, S.H.; Kwon, D.H.; Kim, H.R.; Kang, S.W. Enhancement of sensitivity using gold nanorods-Antibody conjugator for detection of E. coli O157:H7. Sens. Actuat. B Chem. 2010, 143, 784-788.

16. Linman, M.J.; Sugerman, K.; Cheng, Q. Detection of low levels of Escherichia coli in fresh spinach by surface plasmon resonance spectroscopy with a TMB-based enzymatic signal enhancement method. Sens. Actuat. B Chem. 2010, 145, 613-619.

17. Subramanian, A.; Irudayaraj, J.; Ryan, T. A mixed self-assembled monolayer-based surface plasmon immunosensor for detection of E. coli O157:H7. Biosens. Bioelectron. 2006, 21, 998-1006.

18. Taylor, A.D.; Yu, Q.; Chen, S.; Homola, J.; Jiang, S. Comparison of E. coli O157:H7 preparation methods used for detection with surface plasmon resonance sensor. Sens. Actuat. B Chem. 2005, 107, 202-208.

19. Tanaka, H.; Hanasaki, M.; Isojima, T.; Takeuchi, H.; Shiroya, T.; Kawaguchi, H. Enhancement of sensitivity of SPR protein microarray using a novel 3D protein immobilization. Colloid. Surf. B Biointerf. 2009, 70, 259-265.

20. Mazumdar, S.D.; Hartmann, M.; Kämpfer, P.; Keusgen, M. Rapid method for detection of Salmonella in milk by surface plasmon resonance (SPR). Biosens. Bioelectron. 2007, 22, 2040-2046.

21. Skottrup, P.; Hearty, S.; Frøkiær, H.; Leonard, P.; Hejgaard, J.; O’Kennedy, R.; Nicolaisen, M.; Justesen, A.F. Detection of fungal spores using a generic surface plasmon resonance immunoassay. Biosens. Bioelectron. 2007, 22, 2724-2729.

22. Skottrup, P.; Nicolaisen, M.; Justesen, A.F. Rapid determination of Phytophthora infestans sporangia using a surface plasmon resonance immunosensor. J. Microbiol. Meth. 2007, 68, 507-515.

23. Leonard, P.; Hearty, S.; Quinn, J.; O’Kennedy, R. A generic approach for the detection of whole Listeria monocytogenes cells in contaminated samples using surface plasmon resonance. Biosens. Bioelectron. 2004, 19, 1331-1335.

24. Skottrup, P.D.; Nicolaisen, M.; Justesen, A.F. Towards on-site pathogen detection using antibody-based sensors. Biosens. Bioelectron. 2008, 24, 339-348.

25. Haines, J.; Patel, P.D. Detection of Foodborne Pathogens Using BIA; Biacore AB Biotechnology note; Biacore AB: Chalfont St Giles, UK, 1995; p. 31.

26. Yang, L.; Bashir, R. Electrical/electrochemical impedance for rapid detection of foodborne pathogenic bacteria. Biotech. Adv. 2008, 26, 135-150. 
27. Sapsford, K.E.; Bradburne, C.; Delehanty, J.B. Sensors for detecting biological agents. Mater. Today 2008, 11, 38-49.

(C) 2011 by the authors; licensee MDPI, Basel, Switzerland. This article is an open access article distributed under the terms and conditions of the Creative Commons Attribution license (http://creativecommons.org/licenses/by/3.0/). 